\title{
How To Build Customer Loyalty: Through Customer Experience, Perceived Price, And Customer Satisfaction
}

\author{
Edhie Budi Setiawan ${ }^{1}$, Dhea Valdhavessa ${ }^{2}$, Hanif Bambang ${ }^{3}$, Sandriana Marina ${ }^{4}$, Linda Desa \\ Fitri Ratu Bilqis ${ }^{5}$, Lira Agusinta ${ }^{6}$, Mochamad Arif Hernawan ${ }^{7}$, Sonya Sidjabat ${ }^{8}$
}

1,2,3,4,6,7,8 Trisakti Institute of Transportation and Logistics, Jakarta, Indonesia.

${ }^{5}$ Trisakti School of Tourism, Jakarta, Indonesia

11edhie.budi@gmail.com, ${ }^{2}$ dhea.valdhavessa98@gmail.com, ${ }^{3}$ hanif.bambang@gmail.com

${ }^{4}$ sandrianamarina09@google.com, ${ }^{5}$ lindadesafitri@stptrisakti.ac.id, ${ }^{6}$ lir4agusinta@gmail.com,

7arifhernawan1112@gmail.com, ${ }^{8}$ sidjabatsonya@gmail.com

\begin{abstract}
The competition to get the highest Market Share among Low-Cost Carrier airlines in Indonesia is getting fierce. Airlines are competing to offer prices that are appropriate for passengers to perceive them in this era of tariff wars. The degree of satisfaction that is felt is needed to get loyal customers. The purpose of this research is to analyze the impact of customer experience and perceived price on customer loyalty through customer satisfaction. The method of analysis in this study uses the SEM-PLS (Structural Equation Model - Partial Least Square) method with 250 respondents taken by purposive sampling. The result of this research is there is effect positive and significant between customer experience on customer satisfaction and customer loyalty, also there is effect of perceived price on customer satisfaction and customer loyalty. Airlines must pay attention to the services provided to create a memorable experience for passengers and adjust prices to be accepted by passengers.
\end{abstract}

Keywords: Customer Experience, Perceived Price, Customer Satisfaction, Customer Loyalty, Low-Cost Carrier

\section{INTRODUCTION}

Indonesia is an archipelago country that has 17,504 islands from Sabang to Merauke which lies 3,977 miles long. The long and wide distances between Indonesian regions have driven the development of the air transportation industry. The high public interest in the presence of air transportation with relatively cheap price offers has resulted in higher competition for Low-Cost Carrier (LCC) airlines. The growth of Low-Cost Carrier (LCC) airlines aims to create an affordable market for the community and fill routes where the market is not yet potential. However, in the first quarter of 2019, there was a negative passenger growth as shown in table 1.

Table 1.Number of domestic passengers in Q1 (in thousands)

\begin{tabular}{llllll}
\hline No. & \multicolumn{1}{c}{ Airlines } & 2018 & 2019 & \multicolumn{1}{c}{ Class } & \multicolumn{1}{c}{ Grown } \\
\hline 1. & Lion Air & $\mathbf{8 , 3 7 9}$ & $\mathbf{5 , 4 5 7}$ & Low Cost & $\mathbf{- 3 5 \%}$ \\
\hline 2. & Garuda Indonesia & 4,527 & 3,504 & Full Service & $-23 \%$ \\
\hline 3. & Citilink & $\mathbf{3 , 1 4 6}$ & $\mathbf{2 , 9 9 3}$ & Low Cost & $\mathbf{- 5 \%}$ \\
\hline 4. & Water batik & 2,883 & 2,474 & Full Service & $-14 \%$ \\
\hline 5. & Sriwijaya Air & 2,316 & 1,715 & Medium & $-26 \%$ \\
\hline 6. & Wing Air & 1,634 & 1,319 & Pioneering & $-20 \%$ \\
\hline
\end{tabular}

Source: Ministry of Transportation (Self-professed)

From table 1, it can be seen that Citilink was able to maintain the best reduction in the number of passengers, namely 5\% compared to other airlines. Citilink Indonesia's airline has received several awards including the Best Low-Cost Carrier Airlines in Indonesia in 2019 and was ranked 20th in the 2019 World's Best Low-Cost Airlines award from Sky Trax. Although it has been designated as the Best Low-Cost Carrier Airlines in Indonesia, Citilink Indonesia airlines have yet to dominate the market share in Indonesia.

In this highly competitive environment, Customer satisfaction is an important aspect that determines the success of an airline, so a good customer experience is required. According to Laming \& Mason (2014), Customer experience is the key to achieving differentiation and overall customer satisfaction strategies, which can increase loyalty and advocacy, and promote business growth. Going back to the original question, airlines low-cost airlines 
compete on favorite routes, which are often used as routes that travel with the highest frequency. That condition caused the airline Low-Cost Carrier competing to sell tickets at the lowest price to gain Market Share. However, the price assessment depends on the perception of each passenger. This price perception greatly affects passengers, Perceived Price is a comparison between all the costs he has sacrificed with the benefits he gets from a good or service. Higher flight ticket prices compared to competitors, of course, must be supported by convenience in service and better security, so that passengers feel a fair price which results in satisfaction in consumers. Satisfaction in consumers is what influences consumers in long-term post-flight repurchases which will lead to Customer Loyalty. This research was conducted to determine the effect of the influence of Customer Experience and Perceived Price on Customer Loyalty through Customer Satisfaction. This result is expected to be reflected in maintaining passenger loyalty and overall market share.

\section{LITERATURE REVIEW}

\section{Customer Experience.}

One of the ways to maintain the company's position in dominating the market is by captivating the hearts of consumers and providing an impressive experience of the services we provide. Customer Experience is a reaction from customers as a result of direct or indirect interactions with the organization/company. Customer experience aims to drive the company's success by creating a consumer experience that is different from that of competitors, and consumers are willing to pay for it (Laming \& Mason, 2014). Laming \& Mason (2014), they define "customer experience" as a physical and emotional experience that occurs through interaction with brand products and/or services (from direct contact to the post-consumer stage). Some of the characteristics possessed by Customer Experience are: Prioritizing passenger experience; Senses, Feelings, and Thoughts; Pay attention to the situation when the passenger uses the service and emphasizes the rationality $\&$ emotionality of passengers.

Schmitt (1999) divides Customer Experience into five dimensions, namely: Sense, Feel, Think, Relate and Act. This dimension was developed by Gentile et al. (2007) which assumes the following customer experience dimensions: Sensorial Component, Emotional Component, Cognitive Component, Pragmatic Component, Lifestyle Component, Relational Component. In this study using research Verhoef et al. (2009) is a development of (Lemon \& Verhoef, 2016) based on the experience of passengers feel the indicators of sense, think, feel, act, and relate related to the airline company.

\section{Perceived Price.}

Price has a big influence on the consumer's assessment of the company (Kaura et al., 2015). According to (Campo \& Yagüe, 2007) supported by product opinions Ha - Brookshire \& Yoon (2012), Perceived Price is defined as something that is given or sacrificed by consumers to get something. This is in line with research by (Sánchez et al., 2006) which states that Perceived Price can be defined as a customer assessment of the average price of services compared to competitors. Usually, the lower the perceived price, the lower the perceived sacrifice (Martín- Consuegra et al., 2007). Perceived Price is the price received by consumers to get the brand chosen for the type of product (Shirai \& Bettman, 2005). Perceived Price is subjective depending on the passenger's response, so that the evaluation of the price is not the same, depending on the passenger's own opinion. This research indicator refers to Kim et al. (2012), by using three indicators to perceive prices, namely: price expensive, moneysaving, and discount.

\section{Customer Satisfaction.}

Customer satisfaction is assessed from the resulting performance compared to customer expectations, if the performance exceeds expectations, the customer will be satisfied. Customer satisfaction is caused by the cognitive or emotional response to a series of long-term services (Hu et al., 2009). Lin et al. (2015) and Leong et al., (2015) By comparing the perceived performance of the product with expectations, customer satisfaction is defined as an individual's perception of dissatisfaction or pleasure. The indicators used in this study refer to Setiawan et al. (2020) which is a modification of Taylor \& Baker (2000) namely: pleasure in service, the fulfillment of expectations, and satisfying experiences.

\section{Customer Loyalty.}

Customer loyalty is a structure of extensive research used in marketing research to maintain sales market share. According to Griffin, (2007) Loyalty is a form of behavior in which decision-making departments continuously purchase company goods/services. Customer loyalty by some researchers is divided into two, namely behavioral and attitude loyalty. The behavioral loyalty is reflected in the behavior of customers when they buy back a brand or service because they like it (Jiang et al., 2015; Zeithaml et al., 1996), while attitude loyalty refers to the emotional and psychological desire of customers to repurchase and recommend to other people (Baumann 
et al., 2012; Wong \& Zhou, 2006). This concept involves the customer's commitment and support for resubscription, and willingness to pay more for products or services that will continue to be liked in the future. (Agustin \& Singh, 2005; Ladhari, 2009; Chai et al., 2015). Passenger loyalty is needed to increase market share, hoping that they will be loyal to the airline and willing to recommend it to other passengers. The indicators in this study refer to Deng et al. (2010) namely: Continuous use of a particular service provider; Recommending a particular service provider to others; and Loyalty to a particular service provider.

\section{The effect of Customer Experience on Customer Satisfaction.}

Customer Experience is the overall subjective response of customers either directly or indirectly to the company (Lemke et al., 2011; Walter, 2011). The customer experience comes from the unity of interaction between the customer and the product, the company or the various parts of the organization, and this interaction will cause a reaction. The expectations and expectations of customer needs are the indicators that must be met to achieve an unforgettable experience and improve customer satisfaction. Customer satisfaction is the culmination of a series of customer experiences, or it can be said that it is the evaluation result of good minus bad

(Parcell, 2007).

H1: Customer Experience has a positive effect on Customer Satisfaction.

\section{The effect of Perceived Price on Customer Satisfaction.}

Price is an important factor for consumers to purchase, so it has a major impact on the company's consumer evaluation (Kaura et al., 2015). According to to Zeithaml (1988) supported by the opinion Ha-Brookshire \& Yoon (2012), Perceived price is defined as something that consumers pay or sacrifice in order to obtain something. Therefore, the better the perception of the service price, the higher the customer satisfaction with the service (Setiawan et al., 2020).

H2: Perceived Price has a positive effect on Customer Satisfaction.

\section{The effect of Customer Satisfaction with Customer Loyalty.}

According to Lin, Chen, \& Chiu (2015) supported by research conducted by Leong, Hew, Lee, \& Ooi (2015) By comparing the perceived performance of a product with expectations, customer satisfaction is an individual's perception of dissatisfaction or pleasure. Customer loyalty is established by establishing stable and strong relationships with customers and through customer satisfaction (Dominici \& Guzzo, 2010). If the wishes of the passengers are met he will feel satisfied, and if the expectation is exceeded passengers will feel excited. This condition makes the passengers want to go back satisfaction that is felt over and over, to build loyalty passengers. Thus, the purchase of re-passenger is the benchmark that there is influence between customer satisfaction and customer loyalty.

H3: Customer Satisfaction has a positive effect on Customer Loyalty.

\section{The effect of Customer Experience towards Customer Loyalty.}

One of the factors that can give customer loyalty is Customer experience (Imbug et al., 2018; Santoso et al., 2018). The research by Wijaithammarit dan Taechamaneestit (2012) and Thuan et al. (2015) show that Customer experience influences customer loyalty. Loyalty can show a deep enduring customer commitment to re-subscribe or make selected re-purchases consistently in the future, even if the price offered is higher or is related to several other factors. (Jonathan, 2013). Customer experience outstanding will encourage passengers to repeat the experience again and in the end, will keep the loyalty of passengers. Loyalty can show a deep enduring customer commitment to re-subscribe or make selected re-purchases consistently in the future, even if the price offered is higher or is related to several other factors. (Jonathan, 2013).

H4: Customer Experience has a positive effect on Customer Loyalty.

\section{The effect of Perceived Pricet on Customer Loyalty.}

Perceived Price is the price received by consumers to get the selected brand for the type of product (Shirai \& Bettman, 2005). Perceived Price may also have a direct effect on purchase intention (Kim et al., 2012). Perceived Price can also be defined as a customer's assessment of the average price of service compared to its competitors (Yang \& Peterson, 2004). Thus, if the price offered is acceptable to the passenger and the passenger judges the price accordingly, then the passenger will be willing to pay and make further purchases that will make the passenger loyal.

H5: Customer Experience has a positive effect on Customer Loyalty. 
Based on the description of the theoretical basis above, the conceptual framework is as follows.

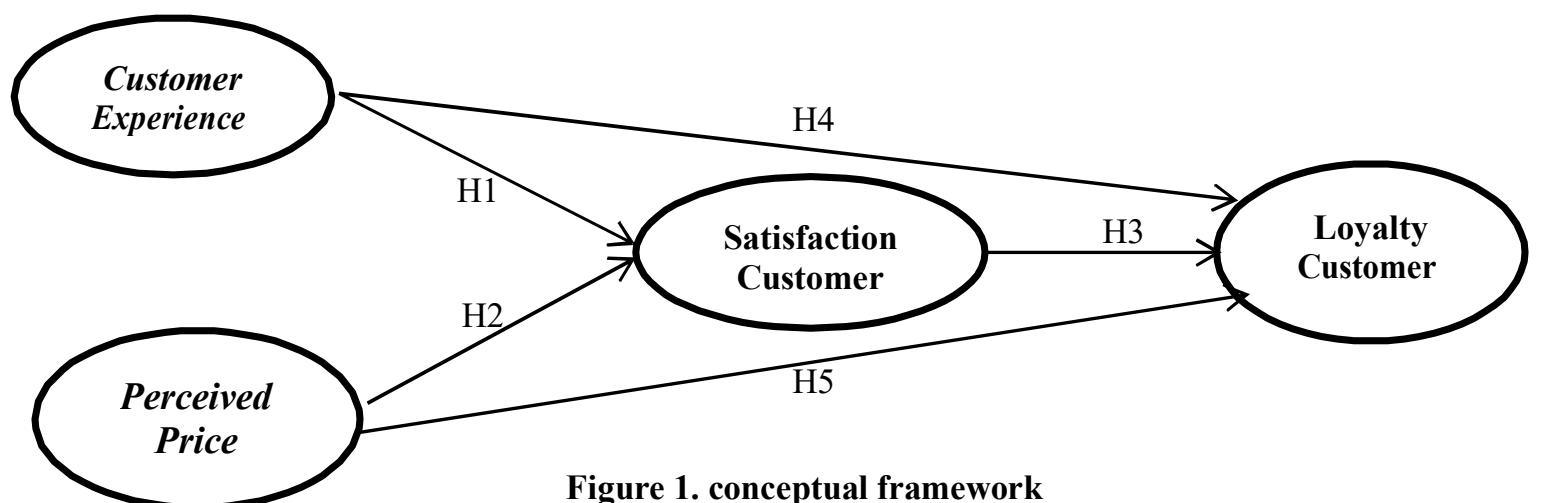

\section{METHODS}

Sampling in this study used purposive sample by distributing questionnaires to250respondents who have used the Citilink Indonesia airline departing or heading to Soekarno-Hatta International Airport, Tangerang. The questionnaire in this study uses a Likert scale which consists of five scales. This research is calculated using SEM (Structural Equation Modeling) analysis method.

The indicators used in this research can be seen in Table 2 as follows:

Table 2. Measurement Indicators

\begin{tabular}{|c|c|c|}
\hline Variable & & Information \\
\hline \multirow{5}{*}{$\begin{array}{l}\text { Customer } \\
\text { Experience }\end{array}$} & CE1 & Citilink Indonesia airline employees are neat and attractive. \\
\hline & CE2 & I am happy to use Citilink Indonesia airline. \\
\hline & CE3 & I am looking for information about the Citilink Indonesia airline. \\
\hline & CE4 & Using Citilink Indonesia airline suits my lifestyle. \\
\hline & CE5 & I promote Citilink Indonesia airline to others. \\
\hline \multirow[t]{3}{*}{$\begin{array}{l}\text { Perceived } \\
\text { Price }\end{array}$} & PP1 & $\begin{array}{l}\text { Citilink Indonesia airline ticket prices may be more expensive than other Low-Cost } \\
\text { Carrier airlines. }\end{array}$ \\
\hline & PP2 & Buying Citilink Indonesia airline tickets might save my expenses. \\
\hline & PP3 & Citilink Indonesia airline provides discounted prices. \\
\hline \multirow{3}{*}{$\begin{array}{l}\text { Customer } \\
\text { satisfaction }\end{array}$} & KP1 & Services offered by Citilink Indonesia are by the standards \\
\hline & KP2 & The services provided by Citilink Indonesia airlines match my expectations. \\
\hline & KP3 & I am satisfied using Citilink Indonesia airline. \\
\hline \multirow{3}{*}{$\begin{array}{l}\text { Customer } \\
\text { loyalty }\end{array}$} & LP1 & I re-purchased Citilink Indonesia airline tickets. \\
\hline & LP2 & I recommend Citilink Indonesia Airlines to others. \\
\hline & LP3 & $\begin{array}{l}\text { I still bought Citilink Indonesia Airline tickets even though my relatives } \\
\text { recommended other airlines. }\end{array}$ \\
\hline
\end{tabular}

\section{RESULTS AND DISCUSSION Outer Model Testing.}

Evaluation of the outer model is carried out to assess the validity and reliability of the model. In the validity evaluation, it was carried out with 2 (two) criteria, namely convergent validity, and discriminant validity, while the reliability evaluation was carried out based on 2 (two) criteria, namely Cronbach alpha and composite reliability.

Validity test.

Table 3. Convergent Validity

\begin{tabular}{ccccc}
\hline Variable & Indicator & Mean & Outer Loading & AVE \\
\hline \multirow{3}{*}{ CE } & CE1 & 4,012 & 0.681 & 0.544 \\
& CE2 & 3,976 & 0.826 \\
\cline { 2 - 4 } & CE3 & 3,768 & 0.755 \\
\cline { 2 - 4 } & CE4 & 4,036 & 0.795 \\
\hline
\end{tabular}




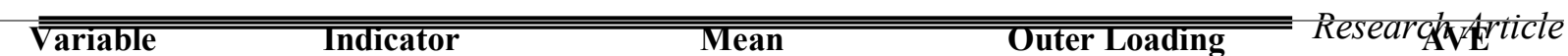

\begin{tabular}{ccccc}
\hline KP & KP1 & 4,012 & 0.798 & 0.581 \\
\cline { 2 - 4 } & KP2 & 3,752 & \\
\cline { 2 - 4 } & KP3 & 3,988 & 0.752 & \\
\hline LP & LP1 & 3,688 & 0.616 \\
& LP2 & 3,992 & 0.732 & \\
\cline { 2 - 4 } & LP3 & 4.06 & 0.786 & 0.769 \\
\hline PP & PP1 & 3,624 & 0.823 & \\
\cline { 2 - 4 } & PP2 & 3,776 & 0.784 & \\
\cline { 2 - 4 } & PP3 & 3,948 & 0.706 & \\
\hline
\end{tabular}

Source: Processed Data (SmartPLS 3.0), 2020

From the results of the calculation of the relationship between latent variables and their indicators, not all of them exceed the specified conditions, namely outer loading $>0.7$, for CE1 and CE5 indicators the outer loading values obtained are only 0.681 and 0.608 this figure is acceptable because it obeys (Hair et al., 2010) for Convergent Validity if the loading value is between 0.5 to 0.6 is considered sufficient. The next analysis is the Average Variance Extract (AVE) value for Convergent Validity assessment, the condition for the AVE value is $>0.5$ so that it can be seen in Table 3 that all latent variables obtain an AVE value $>0.5$. So that based on outer loading and the AVE value obtained, it can be concluded that all indicators or observed variables are significant.

Table 4. Discriminant Validity

\begin{tabular}{ccccc}
\hline & CE & KP & LP & PP \\
\hline CE1 & $\mathbf{0 . 6 8 1}$ & 0.437 & 0.315 & 0.492 \\
\hline CE2 & $\mathbf{0 . 8 2 6}$ & 0.623 & 0.601 & 0.494 \\
\hline CE3 & $\mathbf{0 . 7 5 5}$ & 0.539 & 0.557 & 0.585 \\
\hline CE4 & $\mathbf{0 . 7 9 5}$ & 0.577 & 0.527 & 0.507 \\
\hline CE5 & $\mathbf{0 . 6 0 8}$ & 0.459 & 0.488 & 0.552 \\
\hline KP1 & 0.604 & $\mathbf{0 . 7 9 8}$ & 0.623 & 0.618 \\
\hline KP2 & 0.560 & $\mathbf{0 . 7 5 2}$ & 0.516 & 0.392 \\
\hline KP3 & 0.536 & $\mathbf{0 . 8 0 3}$ & 0.550 & 0.525 \\
\hline LP1 & 0.525 & 0.643 & $\mathbf{0 . 7 3 2}$ & 0.486 \\
\hline LP2 & 0.533 & 0.478 & $\mathbf{0 . 7 8 6}$ & 0.547 \\
\hline LP3 & 0.518 & 0.515 & $\mathbf{0 . 7 6 9}$ & 0.480 \\
\hline PP1 & 0.642 & 0.551 & 0.590 & $\mathbf{0 . 8 2 3}$ \\
\hline PP2 & 0.522 & 0.476 & 0.469 & $\mathbf{0 . 7 8 4}$ \\
\hline PP3 & 0.465 & 0.498 & 0.463 & $\mathbf{0 . 7 0 6}$ \\
\hline
\end{tabular}

Source: Processed Data (SmartPLS 3.0), 2020

It can be seen in Table 4, the numbers in bold indicate that the correlation value between constructs is greater than the correlation value between constructs and other constructs, thus it can be concluded that the construct or latent variable already has good Discriminant Validity.

\section{Reliability Test}

From the results of the SmartPLS 3.0 output (table 5) all variables show Cronbach alpha and composite values with the majority of values $>0.7$ although the customer satisfaction, customer loyalty, and perceived price variables have Cronbach alpha values of 0.640, 0.690, and 0.661, this is still acceptable. (Hair et al., 2010). Thus, it can be concluded that the construct has good reliability by the required minimum limit.

Table 5. Cronbach Alpha and Composite Reliability Cronbach's Alpha

\section{Composite Reliability}

\begin{tabular}{cll} 
Customer Experience & 0.787 & 0.855 \\
\hline Customer satisfaction & 0.640 & 0.806 \\
Customer loyalty & 0.690 & 0.828 \\
\hline Perceived Price & 0.661 & 0.816 \\
\hline
\end{tabular}

Source: Processed Data (SmartPLS 3.0), 2020

\section{Inner Model Testing}

From the output of the algorithm calculation, the R-Square value (table 6) uses these two variables because they are variables that are influenced by other variables. As seen in Tableseen6, the R-Square value for 
the Customer Satisfaction (KP) variable is 0.604 and for the Customer Loyalty (LP) variable is 0.567 . These results indicate that $60.4 \%$ of the Customer Satisfaction (KP) variable is influenced by the Customer Experience (CE) and Perceived Price (PP) variables, while the Customer Loyalty variable shows that $56.7 \%$ is influenced by the Customer Experience (CE) variable. Customers (KP) and Perceived Price (PP)

Table 6. R-Square of Endogenous Latent Variables

\begin{tabular}{ccc}
\hline & R Square & Adjusted R Square \\
\hline Customer Satisfaction & 0.604 & 0.599 \\
\hline Customer Loyalty & 0.567 & 0.563 \\
\hline
\end{tabular}

Source: Processed Data (SmartPLS 3.0), 2020

\section{Hypothesis test}

The results of the Smart PLS calculation are as follows:

Table 7. Path Coefficient

\begin{tabular}{cccccc}
\hline & Hypothesis & Loading Factor & STDEV & T -Statistics & P -Values \\
\hline $\mathrm{H} 1$ & $\begin{array}{c}\text { CustomExperiencence - } \\
\text { Customer Loyalty }\end{array}$ & 0.242 & 0.050 & 4,862 & 0,000 \\
\hline $\mathrm{H} 2$ & $\begin{array}{c}\text { Customer Experiance -> } \\
\text { Customer Satisfaction }\end{array}$ & 0.513 & 0.070 & 7,353 & 0,000 \\
\hline $\mathrm{H} 3$ & $\begin{array}{c}\text { Customer Satisfaction -> } \\
\text { Customer Loyalty }\end{array}$ & 0.395 & 0.061 & 6,493 & 0,000 \\
\hline $\mathrm{H} 4$ & $\begin{array}{c}\text { Perceived Price_-> } \\
\text { Customer Loyalty }\end{array}$ & 0.230 & 0.060 & 3,838 & 0,000 \\
\hline $\mathrm{H} 5$ & $\begin{array}{c}\text { Perceived Price_-> } \\
\text { Customer Satisfaction }\end{array}$ & 0.296 & 0.065 & 4,588 & 0,000 \\
\hline
\end{tabular}

Source: Processed Data (SmartPLS 3.0), 2020

The magnitude of the direct influence and the value of the $t$-statistic for Customer experience and perceived price for customer loyalty through Customer Satisfaction can be seen in Figures 2 and 3.

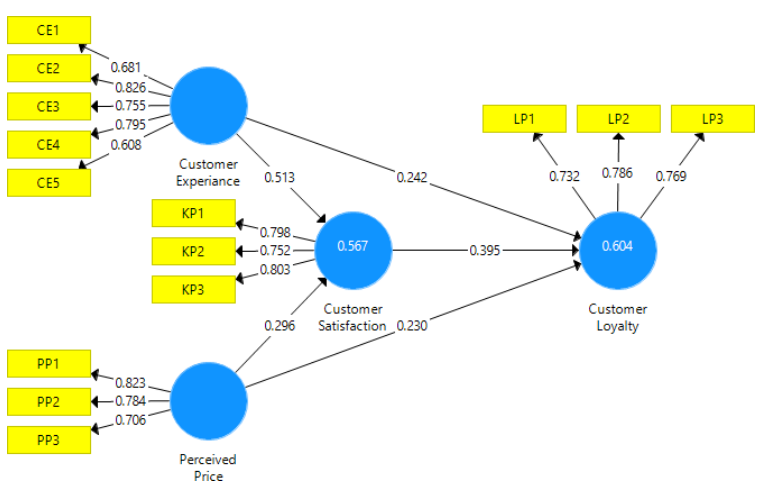

Figure 2. Path Coefficients

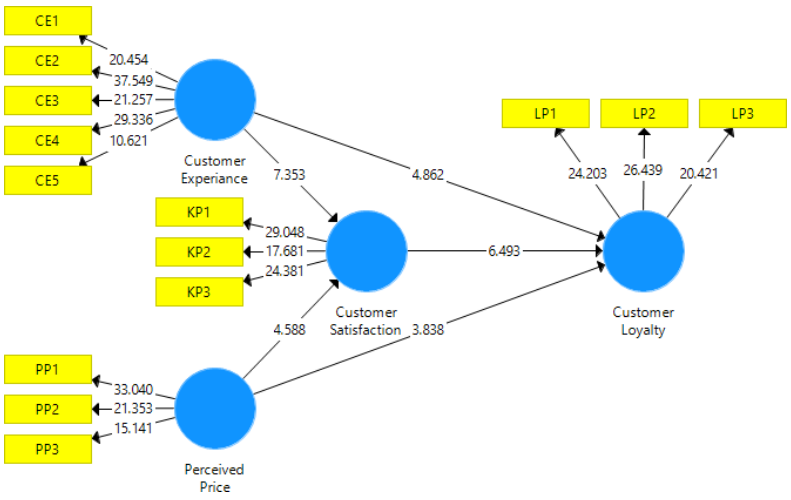

Figure 3. T-Statistic

Source: Processed Data (SmartPLS 3.0), 2020

The result of the evaluation of the path coefficient value shows that there is a relationship between the variables of each variable as indicated by the path coefficient value and the T-Statistics value $\geq$ the T-table value (1,960). For P-Value values, all paths are accepted because the P-Value $\leq 0.05$. With these results it can be concluded that H1, H2, H3, H4, and $\mathrm{H} 5$ can be accepted and states that 5 indicators of Customer Experience, namely Sense, Think, Feel, Act and Relate have a positive and significant relationship to Customer Satisfaction and Customer Loyalty and 3 (three ) indicators of Perceived Price, namely price expensive,money-saving and discounts have a positive and significant relationship to Customer Satisfaction and Customer Loyaltyas shown in table 7 .

To test Hypothesis 6, the $\mathrm{t}$ value is 4.607, which means it is greater than the t-table, which is 1.960 , it can be stated that the mediation parameter is significant. Thus the indirect influence model of the Customer Experience 
variable on customer loyalty through the customer satisfaction variable is significant, so Hypothesis 6 is accepted. Meanwhile, for testing Hypothesis 7, the t value is obtained 3,850 which means it is greater than the t-table is (1.960), it can be stated that the mediation parameter is significant. Thus the indirect influence model of the Perceived Price variable on customer loyalty through the customer satisfaction variable is significant, so Hypothesis 7 is accepted. Furthermore, the relationship between variables according to the calculation results can be seen in table 8 .

Table 8. Indirect Coefficient

\begin{tabular}{lccc}
\hline & Koef. Indirect & t-Statistics & P-Value \\
\hline $\begin{array}{l}\text { Customer Experience -> Customer Satisfaction - } \\
>\text { Customer Loyalty }\end{array}$ & 0.202 & 4,607 & 0,000 \\
\hline $\begin{array}{l}\text { Perceived Price -> Customer Satisfaction -> } \\
\text { Customer Loyalty }\end{array}$ & 0.117 & 3,850 & 0,000 \\
\hline
\end{tabular}

Source: Processed Data (SmartPLS 3.0), 2020

\section{CONCLUSION}

Customer experience has a significant and positive impact on customer satisfaction, and customers are happy to use Citilink Indonesia, which has the greatest impact on customer satisfaction. Perceived price has a significant positive impact on customer satisfaction. The most influential factor is the air ticket price of Citilink Indonesia. Although it is more expensive than other low-cost airlines, the price offered is still acceptable to passengers. This shows that airlines must always maintain passenger awareness of prices by maintaining passenger satisfaction.

The impact of customer experience on customer loyalty is positive and important. The most influential indicator is pleasure, and the desire to understand knowledge affects customer loyalty. The impact of perceived price on customer loyalty is positive and significant. The most influential indicator is to compare with other airlines and save money. Similarly, customer satisfaction has a positive and significant impact on customer loyalty, and the biggest influencing factor is satisfaction when using airlines.

For the indirect effect of customer experience on customer loyalty through customer satisfaction, significant results are obtained. Likewise, the effect of perceived price on customer loyalty through customer satisfaction obtained significant results.

\section{Suggestion.}

Airlines must pay more attention to the services provided to create a memorable experience for passengers and airlines must also adjust prices so that the price offered is always acceptable to customers and does not change passengers' perceptions. For further research, it is recommended to conduct Low-Cost Carrier research in other countries so that it can compare with Low-Cost Carrier conditions in Indonesia. expand the object of research. Besides, this research needs to be carried out for different types of industries, for example, tourism, hospitality, and other industries

\section{REFERENCE}

1. Agustin, C., \& Singh, J. (2005). Curvilinear effects of consumer loyalty determinants in relational exchanges. Journal of Marketing Research, 42(1), 96-108.

2. Baumann, C., Hamin, H., \& Tung, R. L. (2012). Share of wallet in retail banking: a comparison of Caucasians in Canada and Australia vis-à-vis Chinese in China and overseas Chinese. International Journal of Bank Marketing.

3. Campo, S., \& Yagüe, M. J. (2007). Effects of price promotions on the perceived price. International Journal of Service Industry Management. https://doi.org/10.1108/09564230710751488

4. Chai, J. C. Y., Malhotra, N. K., \& Dash, S. (2015). The impact of relational bonding on intention and loyalty. Journal of Hospitality and Tourism Technology, 6(3), 203-227. https://doi.org/https://doi.org/10.1108/jhtt-08-2014-0035

5. Deng, Z., Lu, Y., Wei, K. K., \& Zhang, J. (2010). Understanding customer satisfaction and loyalty: An empirical study of mobile instant messages in China. International Journal of Information Management, 30(4), 289-300. https://doi.org/10.1016/j.ijinfomgt.2009.10.001

6. Dominici, G., \& Guzzo, R. (2010). Customer satisfaction in the hotel industry: A case study from Sicily. International Journal of Marketing Studies, 2(2), 3-12.

7. Gentile, C., Spiller, N., \& Noci, G. (2007). How to sustain the customer experience:: An overview of experience components that co-create value with the customer. European Management Journal, 25(5), 
395-410.

8. Griffin, R. (2007). Modernism and Fascism: the Sense of a Beginning under Mussolini and Hitler. Springer.

9. Ha-Brookshire, J., \& Yoon, S. H. (2012). Country of origin factors influencing USconsumers' perceived price for multinational products. Journal of Consumer Marketing, 29(6), 445-454. https://doi.org/10.1108/07363761211259250

10. Ha-Brookshire, J., \& Yoon, S. (2012). Country of origin factors influencing US consumers' perceived price for multinational products. Journal of Consumer Marketing.

11. Hair et al. (2010). Multivariate Data Analysis. Seventh Edition. Prentice-Hall. In England: Pearson.

12. Hu, H.-H., Kandampully, J., \& Juwaheer, T. D. (2009). Relationships and impacts of service quality, perceived value, customer satisfaction, and image: an empirical study. The Service Industries Journal, 29(2), 111-125.

13. Imbug, N., Ambad, S. N. A., \& Bujang, I. (2018). The Influence of Customer Experience on Customer Loyalty in Telecommunication Industry. International Journal of Academic Research in Business and Social Sciences, 8(3). https://doi.org/10.6007/ijarbss/v8-i3/3909

14. Jiang, X., Jiang, F., Cai, X., \& Liu, H. (2015). How does trust affect alliance performance? The mediating role of resource sharing. Industrial Marketing Management, 45, 128-138.

15. Jonathan, H. (2013). Analisis Pengaruh E-Service Quality terhadap Customer Satisfaction yang Berdampak pada Customer Loyalty PT Bayu Buana Travel Tbk. The Winners, 14(2), 104. https://doi.org/10.21512/tw.v14i2.650

16. Kaura, Prasad, D., \& Sharma. (2015). Service quality, service convenience, price and fairness, customer loyalty, and the mediating role of customer satisfaction. International Journal of Bank Marketing, 33(4), 404-422. https://doi.org/10.1108/IJBM-04-2014-0048

17. Kim, H. W., Xu, Y., \& Gupta, S. (2012). Which is more important in Internet shopping, perceived price or trust? Electronic Commerce Research and Applications, 11(3), 241-252. https://doi.org/10.1016/j.elerap.2011.06.003

18. Ladhari, $R$. (2009). Service quality, emotional satisfaction, and behavioral intentions. Managing Service Quality: An International Journal.

19. Laming, C., \& Mason, K. (2014). Customer experience - An analysis of the concept and its performance in airline brands. Research in Transportation Business and Management, 10, 15-25. https://doi.org/10.1016/j.rtbm.2014.05.004

20. Lemke, F., Clark, M., \& Wilson, H. (2011). Customer experience quality: an exploration in business and consumer contexts using the repertory grid technique. Journal of the Academy of Marketing Science, 39(6), 846-869.

21. Lemon, K. N., \& Verhoef, P. C. (2016). Understanding customer experience throughout thecustomer journey. Journal of Marketing. https://doi.org/10.1509/jm.15.0420

22. Leong, L. Y., Hew, T. S., Lee, V. H., \& Ooi, K. B. (2015). An SEM-artificial-neural-network analysis of the relationships between SERVPERF, customer satisfaction, and loyalty among low-cost and fullservice airlines. Expert Systems with Applications, 42(19), 6620-6634. https://doi.org/10.1016/j.eswa.2015.04.043

23. Lin, R. ., Chen, R. ., \& Chiu, K. K. . (2015). Customer relationship management andinnovation capability: An empirical study. Industrial Management \& Data System, 111-133.

24. Martín-Consuegra, D., Molina, A., \& Esteban, A. (2007). An integrated model of price, satisfaction, and loyalty: an empirical analysis in the service sector. Journal of Product \& Brand Management, 16(7), 459-468. https://doi.org/10.1108/10610420710834913

25. Parcell, D. (2007). Understanding customer experience. Harvard Business Review, 85(6), 137.

26. Sánchez, J., Callarisa, L., Rodríguez, R. M., \& Moliner, M. A. (2006). Perceived value of the purchase of a tourism product. Tourism Management. https://doi.org/10.1016/j.tourman.2004.11.007

27. Schmitt, B. (1999). Experiential marketing. Journal of Marketing Management, 15(1-3), 53-67.

28. Setiawan, E. B., Wati, S., Wardana, A., \& Ikhsan, R. B. (2020). Building trust through customer satisfaction in the airline industry in Indonesia: Service quality and price fairness contribution. Management Science Letters, 10(5), 1095-1102.

29. Shirai, M., \& Bettman, J. R. (2005). Consumer expectations concerning timing and depth of the next deal. In Psychology and Marketing. https://doi.org/10.1002/mar.20068

30. Taylor, S. A., \& Baker, T. L. (1994). An assessment of the relationship between service quality and customer satisfaction in the formation of consumers' purchase intentions. Journal of Retailing, 70(2), 163-178.

31. Thuan, L. T., Ngoc, N. H. B., \& Trang, N. T. N. (2015). Does customer experience management impact customer loyalty shopping at supermarketsrket? The case in the Mekong Delta, Vietnam.

32. Tuwisna, T., Gadeng, T., \& Anggraini, L. (2017). PENGARUH CUSTOMER VALUE DANCUSTOMER EXPERIENCE TERHADAP CUSTOMER SATISFACTION PADA PT. BANK MANDIRI(PERSERO) 
KCP SABANG. Prosiding SEMDI-UNAYA (Seminar Nasional Multi Disiplin Ilmu UNAYA), 1(1), 494506.

33. Verhoef, P. C., Lemon, K. N., Parasuraman, A., Roggeveen, A., Tsiros, M., \& Schlesinger, L. A. (2009). Customer experience creation: Determinants, dynamics,s, and management strategies. Journal of Retailing, 85(1), 31-41.

34. Walter, U. (2011). Drivers of customers' service experiences: a customer perspective on co-creation of restaurant services, focusing on interactions, processe,s and activities. ÖrebroUniversitett.

35. Wijaithammarit, S., \& Taechamaneestit, T. (2012). The impact of customer experience managementon customer loyalty of supercenter's shopper in Thailand. International Journal of E-Education, eBusiness, e-Management and e-Learning, 2(6), 473-477.

36. Wong, A., \& Zhou, L. (2006). Determinants and outcomes of relationship quality: a conceptualmodel and empirical investigation. Journal of International Consumer Marketing, 18(3), 81-105.

37. Yang, Z., \& Peterson, R. T. (2004). Customer perceived value, satisfaction, and loyalty: The role of switching costs. Psychology and Marketing. https://doi.org/10.1002/mar.20030

38. Zeithaml, V. A. (1988). Consumer perceptions of price, quality, and value: a means-end model and synthesis of evidence. Journal of Marketing, 52(3), 2-22.

39. Zeithaml, V. A., Berry, L. L., \& Parasuraman, A. (1996). The behavioral consequences of service quality. Journal of Marketing, 60(2), 31-46. 